\title{
Újdonságok a prosztatarák diagnosztikájában és kezelésében
}

\author{
Riesz Péter dr. - Nyírády Péter dr. \\ Semmelweis Egyetem, Általános Orvostudományi Kar, Urológiai Klinika és Uroonkológiai Centrum, Budapest
}

\begin{abstract}
Az elmúlt évekhez hasonlóan továbbra is a prosztatarákkal kapcsolatban jelenik meg a legtöbb új információ az urológiai daganatok közül. Ez a tendencia több okra vezethető vissza, ami közül minden bizonnyal a legfontosabb, hogy a leggyakoribb urológiai malignomáról van szó. Mindemellett nem lehet csak a magas incidenciára visszavezetni azt, hogy 2014-ben és 2015 első fél évében is fontos új ismeretekkel gyarapodhattunk. A megismert közlemények között természetesen vannak magas evidenciával rendelkező munkák, hosszú időn keresztül zajlott klinikai vizsgálatok és vannak kezdeti, egyelőre biztató eredményeket mutató publikációk. A dolgozatban szerepelnek a szúrést, a mágneses rezonanciás vizsgálatra alapozott eljárást, a kezelést, az aktív követést, a pozitronemissziós tomográfia/komputertomográfia alkalmazását, a citoreduktív prostatectomiát és a gyógyszeres kezelést is érintő újdonságok. Orv. Hetil., $2016,157(11), 410-414$.
\end{abstract}

Kulcsszavak: prosztatarák, uroonkológia, szürés, biopszia, radikális prostatectomia

\section{Novelties in diagnostics and treatment of prostate cancer}

Similarly to earlier years, a vast majority of novel findings were published on prostate cancer, which is the most common urological cancer. Clinical trials with long-term follow-up and promising observational studies were published. In this paper the author reviews the relevant novelties including the diagnostic use of magnetic resonance imaging and positron emission tomography/computed tomography as well as active surveillance, cytoreductive prostatectomy and medical treatment.

Keywords: prostate cancer, uro-oncology, screening, biopsy, radical prostatectomy

Riesz, P. [Novelties in diagnostics and treatment of prostate cancer]. Orv. Hetil., 2016, 157(11), 410-414.

(Beérkezett: 2015. november 21.; elfogadva: 2016. január 20.)

\section{Rövidítések}

$B R C A 1=$ breast cancer $1 ; B R C A 2=$ breast cancer $2 ; \mathrm{MRI}=$ mágneses rezonanciás vizsgálat; PSA = prosztataspecifikus antigén; PSMA = prosztataspecifikus membránantigén; SPCG-4 = Scandinavian Prostate Cancer Group Study 4

\section{Szürés}

A prosztatarákkal foglalkozó közlemények sokszínűségét az adja, hogy a szerteágazó kutatások témaköre a szưréstől kezdve egészen a metasztatikus kasztrációrezisztens, gyógyíthatatlan beteg fájdalomcsillapításáig terjed. Régi törekvés a prosztatarák szűrésének fejlesztése, az, hogy a prosztataspecifikus antigén (PSA-) alapú szűrés/korai felismerés hatékonyságát növelni tudjuk. Amióta a PSA- vizsgálatot bevezették és az urológusok eszköztárába kerülhetett, tudjuk, hogy a hatalmas segítség mellett a hamis pozitív eredmények miatt sok problémának a gyökerét is adja. A cél, hogy a daganat felismerésében jobb szenzitivitású és specificitású módszer álljon rendelkezésre, és lehetőség szerint a klinikailag szignifikáns, nagyobb volumenü és/vagy magas Gleason-score-ral rendelkező rákot mutassa ki. Sokak szerint az előrelépést a genetikai vizsgálatok fogják meghozni.

2014-ben ismertették az IMPACT vizsgálat kezdeti biztató eredményeit. Ez az első prospektív vizsgálat, amely a csírasejtes genetikai markerek előnyét mutatta a magas kockázatú prosztatarák azonosításában [1]. 2481 férfinál végeztek célzott prosztatarákszűrést a $B R C A 1$ (breast cancer 1) és BRCA2- (breast cancer 2) mutáció 
vizsgálatával. Prosztatabiopsziát $3,0 \mathrm{ng} / \mathrm{ml}$ PSA-érték felett végeztek, így az összes betegre vetítve 8\% (119 eset) volt a biopsziák aránya. A pozitív prediktív értéket jelentősen emelte a $B R C A 2$ vizsgálata $(48 \%$ vs. $33 \%)$ és a $B R C A 1$ vizsgálata $(37 \%$ vs. $23 \%)$. Az előzetes eredmények alapján a PSA-szürést $B R C A 2$-vizsgálattal kiegészítve növelhető a klinikailag szignifikáns prosztatarák felfedezése (1. táblázat).

1. táblázat | Célzott prosztatarákszűrés eredménye a $B R C A 1$ - és $B R C A 2$ mutáció vizsgálatával (IMPACT vizsgálat)

\begin{tabular}{lllll}
\hline & \multicolumn{4}{c}{ Gén } \\
\cline { 2 - 5 } & BRCA1+ & BRCA1- & BRCA2+ & BRCA2- \\
\hline Betegek száma & 791 & 531 & 731 & 428 \\
$\begin{array}{l}\text { Pozitív biopsziák } \\
\text { száma }\end{array}$ & 18 & 10 & 24 & 7 \\
$\begin{array}{l}\text { A biopszia pozitív } \\
\text { prediktív értéke (\%) }\end{array}$ & 37,5 & 23,3 & 48,0 & 33,3 \\
\hline
\end{tabular}

\section{MRI-célzásos biopszia}

Nagyszámú közlemény születik a diagnosztika pontosításáról, ahol elsősorban a mágneses rezonanciás (MR-) vizsgálat áll a középpontban, illetve az MRI-célzással végzett vagy megtervezett szövettani vizsgálat. Jelenleg azonban a diagnosztikában igazán komoly előrelépésnek számító (3 Tesla) multiparametrikus MR-vizsgáló készülékek elérhetősége még a legfejlettebb egészségüggyel rendelkező országokban sem teljes, illetve érzékenységének határt szab az, hogy milyen felkészültségû radiológus értékeli. Hu és munkatársainak közleménye ismét megerősíti az MRI előnyét a konvencionális ultrahangvezérelt biopsziával szemben. Vizsgálatukban azt a kérdést teszik fel, hogy MR-célzott prosztatabiopsziával jobban kiválaszthatóak-e azok a betegek, akik alkalmasak az aktív követésre, illetve az Epstein-kritériumok alkalmasak-e még kockázatbesorolásra [2]. Azoknál a férfiaknál, akiknél a biopszia alapján alacsony kockázatú prosztatarákot diagnosztizáltak, multiparametrikus MRI-ultrahang-fúziós megerősítő biopsziát végeztek. Eredményeik szerint gyakrabban volt kimutatható az Epstein-kritériumokat meghaladó daganat, így egyrészt az MRI alkalmazásának az előnyét igazolták az agresszívebb daganatok kimutatásában, másrészt véleményük szerint adataik arra utalnak, hogy az Epstein-kritériumokat újra kell értékelni az aktív surveillance indikációjával kapcsolatban.

\section{Radikális prostatectomia vagy watchful waiting}

A szövettani és képalkotó vizsgálatokkal igazolt, szervre lokalizált prosztatarák esetében továbbra is a helyét keresi a kezelési stratégiák között az aktív követés. A több mint 20 éve indított Scandinavian Prostate Cancer
Group Study 4 (SPCG-4) vizsgálat 18 évet összesítő eredményeinek megismerése segítséget nyújt a tájékozódásban, de egyértelmü, mindenkire igaz konklúziót nem lehet belóle levonni. A radikális prostatectomia vagy watchful waiting a korai prosztatarákban címú dolgozatukban átlagosan 12,4 évig követett 695 beteg adatait értékelték [3]. A tanulmány erősségei közé tartozik, hogy randomizált, hosszú volt a követési idő, és a prosztataráktól független halálokokat külön értékelték. Hátránya, hogy magas Gleason-score és PSA $(<50 \mathrm{ng} / \mathrm{ml})$ mellett is randomizálásra kerültek betegek, ha nem volt áttétük. Konklúziójuk szerint, minél hosszabb a követési idő, annál jobb a mútétes csoportban a túlélés, de az aktív surveillance jó alternatíva megfelelően kiválasztott betegcsoportnál. A nagy kérdés természetesen a megfelelő csoport meghatározásában van, amire a tanulmány nem ad pontos választ. Amennyiben a részleteket vizsgáljuk, 18 éves követés után az erektilis diszfunkció aránya $84 \%$ a radikális prostatectomiás csoportban és $80 \%$ a watchful waiting tekintetében, a vizeletvesztés aránya $41 \%$, illetve $11 \%$. A betegség további 18 éves kumulatív incidenciára vonatkozó adatait a 2. táblázat mutatja be.

2. táblázat $\mid$ Radikális prostatectomia vagy watchful waiting a korai prosztata rákban - SPCG-4 vizsgálat eredményei

\begin{tabular}{lll}
\hline $\begin{array}{l}\text { A vizsgálat kezdetétől számított } \\
18 \text { éves követés után }\end{array}$ & $\begin{array}{l}\text { Radikális } \\
\text { prostatectomia } \\
\text { után }\end{array}$ & $\begin{array}{l}\text { Watchful } \\
\text { waiting }\end{array}$ \\
\hline Összes halálozás (\%) & 56,1 & 68,9 \\
Prosztatarák okozta halálozás & 17,7 & 28,7 \\
Androgénmegvonásos kezelés & 42,5 & 67,4 \\
alkalmazása (\%) & 49 & 63 \\
Sugárterápia (\%) & 13 & 17 \\
Kemoterápia (\%) & 26,1 & 38,3 \\
Metasztázis megjelenése (\%) & 40 & 60 \\
Betegség progressziója (\%) & & \\
\hline
\end{tabular}

\section{Radikális prostatectomia vagy sugárkezelés}

Sok vizsgálat történik a mútét és sugárkezelés hatékonyságának összehasonlítása céljából, de az eredményeket befolyásolja, hogy nagyon nehéz homogén betegségcsoportokat képezni, így korrekt következtetéseket levonni. Randomizált klinikai vizsgálatok alapján a radikális prostatectomia jobbnak tünik az obszervációhoz képest a prosztatarákos betegek többségében, főként a fiatalabb és közepes/magas kockázatú férfiaknál. Továbbá az is igaz, hogy jelenleg nincs randomizált klinikai vizsgálattal bizonyított evidencia a radioterápia elónyére az obszervációhoz képest. Korai megfigyeléses vizsgálatok a radikális prostatectomiát előnyösebbnek találták a sugárkezeléshez képest szervre lokalizált stádium esetén, különösen, ha szigorúan alkalmazták az onkológiai végpontokat. A legfrissebb adatok alátámasztják a prostatectomia előnyét a fiatalabb, közepes vagy nagy kockázatú 
daganattal kezelt betegeknél. Ez az a csoport, akik leginkább veszélyeztetettek a betegség későbbi progressziójára.

\section{Adjuváns sugárkezelés nyirokcsomó- metasztázis esetén}

A következő izgalmas kérdésben, amiben az elmúlt években még bizonytalanok voltunk, mára bizonyítékokkal rendelkezünk. Melyik az a radikális prostatectomián átesett nyirokcsomó-pozitív beteg, akinél az adjuváns radioterápia előnyt jelent? Abdollah és mtsai publikálták a 2 centrumban, 1107 beteg bevonásával 1988-2010 között zajlott vizsgálat eredményeit, amelyben a nyirokcsomók száma és a daganat karakterisztikája szerint képeztek 5 csoportot [4]. Azt találták, hogy 2 csoportnál adott terápiás előnyt az adjuváns sugárkezelés. Az úgynevezett alacsony volumenú nyirokcsomócsoportban (2 darab pozitív nyirokcsomó), amennyiben közepes vagy magas gradusú volt a daganat (Gleason-score 7-10), és a közepes volumenü nyirokcsomócsoportban (3-4 darab pozitív nyirokcsomó), a daganat gradusától függetlenül. Véleményük szerint nincs előnye a sugárkezelésnek a minimális volumenû nyirokcsomócsoportban (1 darab pozitív nyirokcsomó), a 2 darab pozitív nyirokcsomó, de alacsony gradusú daganat esetén, illetve a magas volumenû nyirokcsomócsoportban ( 5 darab vagy több pozitív nyirokcsomó). Ez utóbbi esetén a hormonmegvonás a kezelési stratégia (3. táblázat).

3. táblázat Csoportok beosztása a pozitív nyirokcsomó alapján (F. Abdollah, J. Clin. Oncol., 2014, 32(35), 3939-3947.)

\begin{tabular}{|c|c|c|}
\hline $\begin{array}{l}\text { Nyirokcsomócsoport } \\
\text { neve }\end{array}$ & Pozitív nyirokcsomók & Adjuváns sugárkezelés \\
\hline Minimális volumenú & 1 darab & Nincs elóny \\
\hline Alacsony volumenű & $\begin{array}{l}2 \text { darab } \\
\text { alacsony gradusú } \\
\text { daganat }\end{array}$ & Nincs elöny \\
\hline Alacsony volumenű & $\begin{array}{l}2 \text { darab } \\
\text { közepes vagy magas } \\
\text { gradusú daganat }\end{array}$ & Előnyös \\
\hline Közepes volumenű & $3-4$ darab & Előnyös \\
\hline Magas volumenü & 5 darab vagy több & Nincs elöny \\
\hline
\end{tabular}

\section{A PET-CT hatékonysága a prosztatarák kiújulásának kimutatásában}

A prosztatarák kuratív kezelését követő relapsusnál az áttétek kutatásában a PET-CT szerepe felértékelődni látszik, de a kolin mellett más molekuláris tracerek segítségét is igénybe veszik a kutatók. A legtöbb tanulmány a PET-CT-nek egyre nagyobb szerepet tulajdonít a prosztatarák kiújulásának felderítésében, azonban felhívják a klinikusok figyelmét arra, hogy a megfelelő betegnél és a megfelelő időben kell elvégezni - azaz akkor, amikor már és még van terápiás konzekvenciája. Azt, hogy mikor alkalmazzuk a PET-CT-t, a beteg és a daganat jellemzőihez kell igazítani. Megerősítést nyert, hogy a kimutatás sikere nagyban PSA-függő, magas a szenzitivitása, de jelenleg lényegesen drágább a többi képalkotóhoz képest (4. táblázat).

4. táblázat |A PET-CT hatékonysága a prosztatarák kiújulásának kimutatásában

A PET-CT hatékonysága a prosztatarák kiújulásának kimutatásában 3 fő faktortól függ

\begin{tabular}{lll}
\hline Betegtörténet & Daganat tulajdonsága & Kiújulás helye \\
\hline Multimodális kezelés & $\begin{array}{l}\text { PSA-érték és -változás a } \\
\text { képalkotás időpontjáig }\end{array}$ & Helyi \\
Hormonmanipuláció & $\begin{array}{l}\text { Prosztatarák gradus és } \\
\text { agresszivitás }\end{array}$ & Nyirokcsomó \\
Képalkotás időpontja & $\begin{array}{l}\text { Prosztatarák-stádium és } \\
\text { elsődleges kezelés }\end{array}$ & Csont \\
\hline
\end{tabular}

Az új tracerek tovább fogják javítani az érzékenységet (recidíva kimutathatóságát) és csökkenteni a vizsgálat negatív prediktív értékét. A legbiztatóbb eredményeket az anti-3-18F-FACBC-vel érték el, amely anyag felvétele összefüggést mutat a daganat funkcionális aktivitásával [5]. A másik kiemelendő tracer, a ${ }^{68} \mathrm{Ga}$-labelled-PSMAligand. A PSMA (prosztataspecifikus membránantigén) egy II. típusú transzmembrán protein, amit a prosztatarák „overexpresszál”, beleértve az androgén független, előrehaladott és metasztatikus betegséget is [6].

\section{A citoreduktív prostatectomia előnyének vizsgálatai}

Csak évek múlva kapunk arra választ, hogy metasztatikus prosztatarák esetén a prosztataeltávolítás és az áttétek sebészi kezelése kinél jelent túlélési és/vagy életminőségbeli előnyt. Azonban a citoreduktív radikális prostatectomiával kapcsolatban egyre több munkacsoport számol be eredményeiről. Hormonmegvonásra jól reagáló betegeknél az adjuváns kezelés után elvégzett citoreduktív prostatectomia javíthatja a teljes és a tünetmentes túlélést. A tanulmányok azonban kiemelik, hogy csak jól kiválasztott betegeknél számolhatunk a fenti előnnyel, illetve azzal, hogy hatékonyan csökkentjük az alsó és a felső húgyúti komplikációk arányát. További kutatásokra van szükség, hogy meghatározzák ezt a megfelelő betegcsoportot [7].

\section{Metasztatikus prosztatarákos betegek primer kemoterápiája vagy primer sugárkezelése}

Az elmúlt év újdonsága a gyógyszeres kezelés területén a nagyméretú áttéttel felfedezett prosztatarákos betegek primer kemoterápiája, de a hosszú távú eredmények még 
itt is váratnak magukra. A randomizált vizsgálatok tervezése során azt a megfigyelést tartották szem előtt a kutatók, hogy az agresszív típusú, metasztatikus prosztatarákban szenvedő betegek a kezelésük során több időt töltenek kasztrációrezisztens állapotban. A hipotézis szerint már a felismeréskor sok a hormonrefrakter daganatsejt, illetve a betegek jobb általános állapotban vannak, amiért a primer kemoterápia előnnyel kecsegtethet. Jelenleg 2 nagy, multicentrikus randomizált vizsgálat zajlik (CHAARTED és GETUG 15), amelyekben az egyik karon a betegek csak hormonterápiát, míg a másik karon hormonterápiát és docetaxel kemoterápiát kapnak. Az első, köztes értékelő eredmények a docetaxelkaron a teljes túlélés és a tünetmentes túlélés növekedését mutatják, a fiatalabb, „jobb” kondíciójú betegeknél $[8,9]$.

A STAMPEDE rövidítésû randomizált vizsgálatban a metasztatikus prosztatarákos betegek csoportjának egyik karja hormonmegvonásban, másik karja hormonmegvonásban és sugárkezelésben részesül. Az eddig hozzáférhető adatok alapján a sugárterápia + ADT hatékonyságot mutat, a csak hormonmegvonáshoz képest. A pontos eredmények 2016. év végére várhatóak [10].

\section{Metasztatikus kasztrációrezisztens prosztatarákos betegek gyógyszeres kezelése}

A gyógyszeres terápiában is ugrásszerü előrelépéseknek vagyunk tanúi és a betegekkel együtt haszonélvezői. 2010 óta a kasztrációrezisztens prosztatarák kezelésében az eddig arany standardnak tekintett taxánkezelés mellett öt új készítmény áll az uroonkológusok rendelkezésére.

5-6 éve még nem gondolhattuk, hogy a metasztatikus kasztrációrezisztens prosztatarákos betegeinken több gyógyszerkészítménnyel segíthetünk. Ma már az életüket hosszabbíthatjuk meg, fájdalmaikat csökkenthetjük és a tünetmentes idejüket tudjuk kitolni. Jelenleg abban a szerencsés helyzetben vagyunk, hogy abban várunk segítséget a klinikai vizsgálatoktól, hogy melyik hatóanyagot válasszuk a többi ellenében, hiszen önállóan mind az 5 készítmény bizonyította hatékonyságát. Olyan prediktív választ meghatározó faktorokra lenne szükség, amelyek abban adnak eligazítást, hogy az adott prosztatarákos sejtvonalnál melyik molekula a hatékonyabb. Jelenleg ilyen markerrel, amit a klinikai gyakorlatban általánosan alkalmazhatunk, még nem rendelkezünk. Vizsgálatok szerint többek között az androgénreceptor V7 variánsa előre jelezheti az abirateron- és az enzalutamidrezisztencia meglétét. Egy betegszámát illetően kis tanulmány 75\%-ban jelezte előre a rezisztens betegek arányát [11]. Továbbá a gyógyszerválasztás során figyelembe kell venni a különböző terápiák mellékhatásprofilját és az anamnesztikus adatok alapján, illetve a beteg általános állapota szerint ezt is szem előtt kell tartani. Az összefoglaló tanulmányok véleménye szerint a betegeket rendszeresen ellenőrizni kell, és nem elég csak a PSA-t követni, hanem az általános egészségügyi állapota, urológiai tünetei és a mellékhatások jelenléte is befolyásolják a következő terápiás döntésünket.

Docetaxelkezelés után másodvonalban, abirateronacetát, cabazitaxel, enzalutamid és radium-223 dichlorid közül történhet a választás. A klinikai vizsgálatok alapján a gyógyszerek kevésbé hatékonyak másod- és azt követő vonalakban, mintha elsőként alkalmazzák. A jelenleg elérhető eredmények szerint úgy tûnik, hogy ha a kasztrációrezisztens prosztatarák jelentős tüneteket okoz, akkor kemoterápia ajánlott elsőként. Kevesebb tünet vagy tünetmentesség esetén az a cél, hogy új generációs hormonkészítményeket tudjunk biztosítani (például abirateron és enzalutamid) a betegeknek. Minden kezelés mellett folytatni kell a folyamatos hormonmegvonást. A gyakorlatban a gyógyszerválasztás döntésében figyelembe kell venni a betegség agresszivitását, a társbetegségeket, a betegek preferenciáit és a hatóanyagok elérhetőségét, mind a földrajzi, mind az egészségbiztosítási támogatottság szempontjából.

\section{Következtetések}

A fentiekből is érthető, hogy az uroonkológiai témájú tudományos kongresszusokon, klinikai vizsgálatokban és közleményekben a prosztatarák témája erősen dominál a többi daganathoz képest. Tovább lehetne idézni a jelenleg is aktívan vizsgált kérdéseket, de így is látható, hogy a prosztatarákkal foglalkozó kutatók, legyenek azok epidemiológusok, radiológusok, urológusok, patológusok, onkológusok vagy sugárterapeuták, 2014-ben, 2015ben és várhatóan a következó években is, sok új válasszal fogják gazdagítani az orvostudományt.

Anyagi támogatás: A közlemény megírása anyagi támogatásban nem részesült.

A szerzők mindketten hozzájárultak a cikk elkészítéséhez, végleges változatát elolvasták és jóváhagyták.

Érdekeltségek: A szerzőknek nincsenek érdekeltségei.

\section{Irodalom}

[1] Bancroft, E. K., Page, E. C., Castro, E., et al.: Targeted prostate cancer screening in BRCAI and BRCA2 mutation carriers: results from the initial screening round of the IMPACT study. Eur. Urol., 2014, 66(3), 489-499.

[2] Hu, J. C., Chang, E., Natarajan, S., et al.: Targeted prostate biopsy in select men for active surveillance: do the Epstein criteria still apply? J. Urol., 2014, 192(2), 385-390.

[3] Bill-Axelson, A., Holmberg, L., Garmo, H., et al.: Radical prostatectomy or watchful waiting in early prostate cancer. N. Engl. J. Med., 2014, 370(10), 932-942.

[4] Abdollah, F., Karnes, R. J., Suardi, N., et al.: Impact of adjuvant radiotherapy on survival of patients with node-positive prostate cancer. J. Clin. Oncol., 2014, 32(35), 3939-3947. 
[5] Nanni, C., Schiavina, R., Brunocilla, E., et al.: 18F-FACBC compared with 11C-choline PET/CT in patients with biochemical relapse after radical prostatectomy: a prospective study in 28 patients. Clin. Genitourin. Cancer, 2014, 12(2), 106-110.

[6] Chakraborty, P. S., Kumar, R., Tripathi, M., et al.: Detection of brain metastasis with 68Ga-labeled PSMA ligand PET/CT: a novel radiotracer for imaging of prostate carcinoma. Clin. Nucl. Med., 2015, 40(4), 328-329.

[7] Faiena, I., Singer, E. A., Pumill, C., et al.: Cytoreductive prostatectomy: Evidence in support of a new surgical paradigm (Review). Int. J. Oncol., 2014, 45(6), 2193-2198.

[8] Liaw, B. C., Shevach, J., Oh, W. K.: Systemic therapy for the treatment of hormone-sensitive metastatic prostate cancer: from intermittent androgen deprivation therapy to chemotherapy. Curr. Urol. Rep., 2015, 16(3), 13

[9] Gravis, G., Marino, P., Joly, F., et al.: Patients' self-assessment versus investigators' evaluation in a phase III trial in non-castrate metastatic prostate cancer (GETUG-AFU 15). Eur. J. Cancer, 2014, 50(5), 953-962.

[10] James, N. D., Spears, M. R., Clarke, N. W., et al.: Survival with newly diagnosed metastatic prostate cancer in the "docetaxel era": Data from 917 patients in the control arm of the STAMPEDE trial (MRC PR08, CRUK/06/019). Eur. Urol., 2015, 67(6), 1028-1038.

[11] Antonarakis, E. S.: Predicting treatment response in castrationresistant prostate cancer: could androgen receptor variant-7 hold the key? Expert Rev. Anticancer Ther., 2015, 15(2), 143-145.

(Riesz Péter dr., Budapest, Üllői út $78 / \mathrm{B}, 1082$ e-mail: rieszp@gmail.com)

\section{Tisztelt Szerzőink, Olvasóink!}

Az Orvosi Hetilapban megjelenő/megjelent közlemények elérhetőségére több lehetőség kínálkozik.

Rendelhető különlenyomat, melynek áráról bővebben a www.akkrt.hu honlapon (Folyóirat Szerzőknek, Különlenyomat menüpont alatt) vagy Szerkesztőségünkben tájékozódhatnak.

A közlemények megvásárolhatók pdf-formátumban is, illetve igényelhető Optional Open Article (www.oopenart.com).

Adott díj ellenében az online közlemények bárki számára hozzáférhetök honlapunkon (a közlemények külön linket kapnak, így más oldalról is linkelhetővé válnak).

Bővebb információ a hirdetes@akkrt.hu címen vagy különlenyomat rendelése esetén a Szerkesztőségtől kérhető. 